\title{
Evaluation of PCR detection of $S$. typhi DNA in the diagnosis of clinically suspected Typhoid fever
}

\author{
A.B. Dey' ${ }^{1}$ Rama Chaudry², Maya Gopinath', D.S. Chandel'2, B.V. Laxmi ${ }^{2}$
}

\begin{abstract}
Abstrak
Demam tifoid merupakan masalah penting bagi kesehatan masyarakat di negara-negara berkembang. Suatu kontrol yang efektif memerlukan deteksi kasus, pengobatan definitif dan eliminasi sumber infeksi serta perbaikan sistem kesehatan masyarakat. Laporan karus yang memadai sering tak dapat dilakukan karena adanya pengobatan empiris dengan antibiotika menurunkan sensitifitas dari hasil isolasi serta kurangnya spesifitas dari pemeriksaan serologis di daerah endemis. Kemampuan dari berbagai pemeriksaan, termasuk biakan darah, tes Widal dan reaksi berantai polimerasa (PCR) untuk deteksi Salmonella typhi dalam usaha diagnosis demam tifoid telah dievaluasi pada 60 penderita tersangka demam enterik. Enampuluh persen penderita telah mendapat pengobatan antibiotika secara empirik sebelum dilakukan pemeriksaan. Tujuhbelas penderita didiagnosis sebagai demam tifoid dan lima lainnya sebagai demam paratifoid. Tigapuluh satu kasus tak dapat didiagnosis dengan cara pemeriksaan mikrobiologi, sedangkan tujuh penderita lainnya menderita berbagai penyakit menular yang lain. Diagnosis demam tifoid ditegakkan secara biakan darah ${ }^{3}$, tes Widal ${ }^{11}$ dan pemeriksaan $P C R^{7}$. Lima dari tujuh penderita dengan hasil PCR positif, negatif secara biakan; sedangkan empat dari II kasus dengan hasil Widal positif telah mendapat terapi antibiotika sebelumnya. Dengan adanya pemberian antibiotika sebelumnya, diagnosis laboratorium demam tifoid belum dapat memberikan hasil yang memuaskan. Walaupun demikian, PCR tampaknya bermanfaat pada beberapa kasus.
\end{abstract}

\begin{abstract}
Typhoid fever is an important public health problem in developing countries. Effective control of the disease requires detection of cases, definitive treatment and elimination of source of infection, and improvement of public health system. Adequate reporting of cases is often not possible as empirical antibiotic therapy decreases the sensitivity of isolation procedures and serological tests lack specificity in endemic areas. The value of various procedures, namely blood culture, Widal test and polymerase chain reaction (PCR) assay for detection of Salmonella typhi, in the diagnosis of typhoid was evaluated in 60 cases with suspected enteric fever. Sixty percent of the cases had received empirical antibiotic treatment prior to investigations. Seventeen patients were labelled with the diagnosis of typhoid and five had paratyphoid. Thirty-one cases could not be ascribed any diagnosis on the basis of microbiological investigations and the rest seven had various other infectious diseases. The diagnosis of typhoid was arrived at by blood culture ${ }^{3}$, Widal test ${ }^{11}$ and PCR assay ${ }^{7}$. Five of the seven PCR positive cases, none of the culture positive cases and four of the eleven Widal positive cases had received prior antibiotic therapy. Laboratory diagnosis of typhoid remains unsatisfactory in presence of prior antibiotic therapy though $P C R$ seems to be a useful investigation in some of these cases.
\end{abstract}

\section{INTRODUCTION}

Enteric fever is a common public health concern in India and most developing societies 1,2 . This acute systemic disease is usually caused by infection with Salmonella typhi and to a lesser extent by Salmonella paratyphi. Typhoid fever is often marked by multisystemic complications and death when diagnosed late or not treated effectively. With little possibility of its complete eradication, early diagnosis and effective treatment are the only means of reducing the impact of typhoid fever.

Department of Medicinel and Department of Microbiology², All India Institute of Medical Sciences, Ansari Nagar, New Delhi-110029 INDIA.
Isolation from peripheral blood by culture is the most definitive diagnostic procedure for detection of $S$. typhi infection. However the culture negativity rates are often as high as $30-65 \% 3,5$. Similarly, serological tests such as Widal test lacks diagnostic utility due to its non-specificity in endemic areas 5,6 though $90 \%$ of bacteriologically confirmed cases have antibodies against $\mathrm{O}$ and $\mathrm{H}$ antigens of the organism. Attempts have been made in the past to develop better methods for diagnosis of the infection with limited success. Several procedures such as counter immuno-electrophoresis 8 , latex agglutination ${ }^{9}$ and coagglutination 10 have been employed in the diagnosis of $S$. typhi infection with poor reproducibility. Application of ELISA techniques for detection of antigens of $S$. typhi and antibodies against it have not also led to a major break through 11,12 . In the last decade, of $S$. typhi by using DNA probes ${ }^{13,14}$ have been attempted in 
clinical samples but has not lived up to their potential due to technical and cost factors. To improve the utility of detection of $S$. typhi DNA as a reliable tool, PCR amplifications has been applied in the diagnosis of typhoid fever in recent years with encouraging results ${ }^{15,17}$. In the present communication, we have evaluated the application of PCR amplification of the $\mathrm{dH}$ flagellin gene in detection of $S$. typhi in patients with suspected enteric fever.

\section{MATERIALS AND METHODS}

\section{Cases}

In a prospective study, consecutive patients with acute febrile illness suspected to have enteric fever were investigated to achieve a definitive diagnosis during the period October 1995 and April 1997. The bases of a clinical diagnosis of enteric fever were i) continous fever for at least 1 week duration, ii) gastrointestinal symptoms, iii) splenomegaly and/or hepatomegaly and iv) response to empirical therapy with ciprofloxacin or second or third generation cephalosporins within 72-96 hours. Patients were investigated according to a pre-designed protocol which included clinical evaluation (history taking and physical examination), routine laboratory investigations comprising of complete blood count, peripheral smear examination for parasites, liver function tests, routine blood chemistry, urinalysis and chest $\mathrm{x}$-ray. Microbiological investigations included aerobic and anaerobic blood culture, urine culture, paired Widal test and PCR amplification and detection of Salmonella typhi DNA from flagellin gene.

\section{PCR for S. typhi}

Three millilitres of venous blood was collected in sterile citrate tube. DNA was extracted from $200 \mathrm{mi}-$ crolitre of blood using the Qiagen blood and body fluid protocol. The extracted DNA was subjected to PCR in the DNA thermocycler (MJ Research Inc Massachusetts, USA). The reaction mixture for PCR contained the extracted DNA, 50 picomoles each of RK1 (5'TGG GCG ACG ATT TCT ATG CC 3') and RK2 (5'TTT CGC GAA CCT GGT TAG CC 3'), 200 micromoles of all four dNTPs, 0.625 unit of Taq polymerase, $2.5 \mathrm{mM} \mathrm{MgCl}_{2}$ and standard PCR buffer to make a final volume of 25 microlitres. Denaturation was achieved at $94^{\circ} \mathrm{C}$ for 1 minute, annealing at $57^{\circ} \mathrm{C}$ for 1 minute 15 seconds and polymerisation at $72^{\circ} \mathrm{C}$ for 3 minutes. The PCR products were subjected to agarose gel electrophoresis, stained with ethidium bromide and examined under ultraviolet illumination. The specificity of RK1 and RK2 primers for $\mathrm{dH}$ flagellin gene has been reported in an earlier publication 17

\section{Controls}

Blood samples from 21 afebrile controls were also subjected to Widal test and PCR amplification for $S$. typhi DNA.

\section{Analysis of data}

A diagnosis of $S$. typhi infection was considered when a case of suspected enteric fever demostrated.

Table 1. Clinical features and laboratory investigations in sixty patients with suspected enteric fever.

\begin{tabular}{|c|c|c|c|}
\hline Clinical features & No $(\%)$ & Laboratory investigations & No $(\%)$ \\
\hline \multicolumn{4}{|l|}{ Symptoms } \\
\hline Fever & $60(100)$ & $(<12 \mathrm{gm} / \mathrm{dl})$ & $15(25)$ \\
\hline Abdominal pain & $12(20)$ & Leucopenia $\left(<4000 / \mathrm{mm}^{3}\right)$ & $28(46.7)$ \\
\hline Diarrhoea & $20(33)$ & Leucocytosis $\left(>11000 / \mathrm{mm}^{3}\right)$ & $3(5)$ \\
\hline Constipation & $5(8.3)$ & Hyperbilirubinaemia (1.8 $\mathrm{mg} \%$ ) & $1(1.66)$ \\
\hline Headache & $38(63.3)$ & $\begin{aligned} \text { Raised ALT } & (>40 \mathrm{IU} / \mathrm{dl}) \\
& (>80 \mathrm{IU} / \mathrm{dl})\end{aligned}$ & $\begin{array}{ll}52 & (86.7) \\
28 & (46.7)\end{array}$ \\
\hline Rectal bleeding & $1(1.7)$ & Raised AST $\quad(>40 \mathrm{IU} / \mathrm{dl})$ & $53(88.3)$ \\
\hline Vomiting & $10(16.7)$ & $(>80 \mathrm{IU} / \mathrm{dl})$ & $26(43.3)$ \\
\hline \multicolumn{4}{|l|}{ Signs } \\
\hline Bradycardia & $43(71.7)$ & Albuminuria $(\geq++)$ & $10(16.7)$ \\
\hline Splenomegaly & $54(90)$ & Urine sediments (RBC, WBC) & $12(20)$ \\
\hline Hepatomegaly & $21(35)$ & Abnormal chest $\mathrm{x}$-ray & $1(3.3)$ \\
\hline Abdominal tenderness & $19(31.7)$ & (miliary mottling) & \\
\hline Chest signs & $11(18.3)$ & & \\
\hline Lymphadenopathy & $2(3.3)$ & $\because$ & \\
\hline
\end{tabular}


1. positive blood culture for $S$. typhi

2. a titre of $\geq 1: 160$ for $\mathrm{O}$ and $\mathrm{H}$ agglutinins on first test or four fold rise in $\mathrm{O}$ and $\mathrm{H}$ agglutinin titres on paired samples

3. demonstration of $S$. typhi DNA after PCR amplification.

\section{RESULTS}

\section{Clinical manifestation}

Sixty patients ( 40 males and 20 females, age range: 9 and 63 years) with acute onset of fever, suspected clinically to have enteric fever were investigated for a definitive diagnosis. The duration of fever at the time of presentation was $8.4( \pm 2.3)$ days (range 7-18 days). Thirty seven patients had received various antimicrobial drugs which included cotrimoxazole ${ }^{18}$, amoxycillin ${ }^{11}$ and ciprofloxacin ${ }^{8}$ for periods varying between 1 and 4 days. The clinical and laboratory manifestations of these patients are presented in Table 1 .

\section{Microbiological profile}

With a diagnostic titre of $1: 160$ for both $\mathrm{O}$ and $\mathrm{H}$ agglutinins 11 patiens had a positive Widal test at the testing. A repeat Widal test was carried out in 37 patients out of 45 cases (excluding 3 cases of typhoid, 5 cases of paratyphoid and 7 cases with non-enteric illnesses) in whom a diagnosis of enteric fever was considered after one week while getting treated for the same. Only two cases showed a four fold or more rise in titres of $\mathrm{O}$ and $\mathrm{H}$ agglutinins over their previous titres fulfilling the criteria for diagnosis for typhoid fever. Thus 13 cases in all had a positive Widal test. Results of Widal test in cases and controls are presented in Table 2.

In 13 cases, a putative causal organism was isolated from blood culture. They included $S$. paratyphi $A$ in five, S. typhi in three, Staphylococcus aureus in two,
Escherichia coli in one, Klebsiella species in one and Enterococcus in one. None of these cases had received pre-investigation antibiotic therapy. Plasmodium vivax was detected in peripheral blood smear in one patient. All the three cases who had $S$. typhi grown in their peripheral blood, had Widal test positive on first testing. Cases of paratyphoid had positive Widal test (high $\mathrm{O}$ agglutinin and high $\mathrm{AH}$ titres) where as all the five cases with septicaemia had nondiagnostic rise in $\mathrm{O}$ and $\mathrm{H}$ agglutinins.

\section{Detection of S. typhi DNA by PCR amplification}

$S$. typhi DNA could be detected in blood samples of seven cases. None of the blood samples from controls were positive for $S$. typhi DNA. One of them had blood culture positive for $S$. typhi and none of them had a positive Widal test on first testing but two of them had four fold or more rise in $\mathrm{O}$ and $\mathrm{H}$ agglutinins on paired serology. All the cases with septicemic illness other than typhoid were PCR negative.

The diagnosis arrived after the investigations are presented in Table 3 . It was observed that nine of the

Table 3. Final diagnosis in sixty patients with suspected enteric fever

\begin{tabular}{lcc}
\hline \multicolumn{1}{c}{ Diagnosis } & No (\%) \\
\hline No diagnosis achieved & $31(51.7)$ \\
Typhoid fever $($ S. typhi) & $17(28.3)$ \\
Culture positive & 3 \\
Widal positive & $11+2$ \\
PCR positive & 7 & \\
Paratyphoid (S. paratyphi A) & 5 & $(8.3)$ \\
Miliary tuberculosis & 1 & $(1.7)$ \\
Malaria (P. vivax) & 1 & $(1.7)$ \\
Miscellaneous bacterial infection & 5 & $(8.3)$ \\
Staphylococcus aures & 2 & \\
Klebsiella species & 1 \\
Escherichia coli & 1 \\
Enterococcus & 1 \\
\hline
\end{tabular}

Table 2. Results of Widal test in cases of suspected enteric fever and afebrile controls

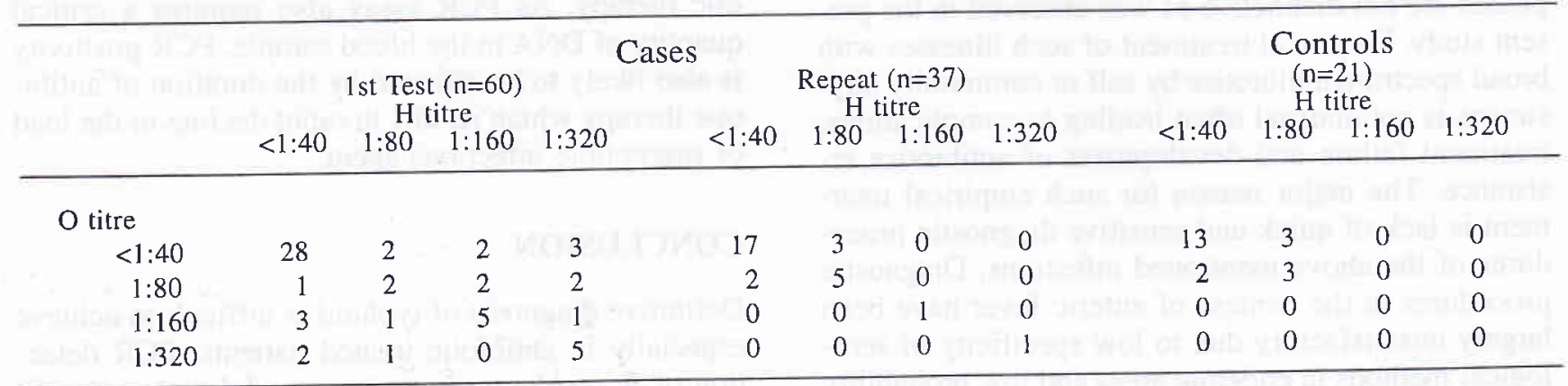


seventeen typhoid cases had received prior antibiotic therapy. Of them five were diagnosed by PCR assay. None of the culture positive cases and four out of eleven Widal positive cases had been treated prior to hospitalisation.

\section{Treatment}

Fourty six patients received ciprofloxacin, eight patients received cefotaxime and four patients were treated with cefuroxime axetil. Patients with malaria and miliary tuberculosis were provided specific treatment. All the cases responded to empirical/specific antibiotic therapy and became afebrile between three and seven days (mean $5.2 \pm 2.1$ days). None of the patients had any complication of typhoid or reported relapse.

\section{DISCUSSION}

In a prospective study of sixty cases with acute onset fever suspected to have enteric fever, a diagnosis of typhoid was considered in 17 patients and paratyphoid in 5 patients. Other septicemic illness were detected in 5 patients. Malaria and tuberculosis was diagnosed in one patient each. In thirty one patients no definitive diagnosis (with microbiological evidence) could be achieved. Failure to reach a diagnosis in such large number of cases may be due to three factor i) cause of fever other than enteric fever i.e. other infections such as viral infections ii) effect of empirical antibiotic therapy prior to investigations and iii) lack of sensitivity of diagnostic procedures to detect $S$. typhi infection. Acute onset febrile illnesses in the community are usually infective in nature and their epidemiology is largely influenced by prevalence of various infectious diseases in a given geographical area18,19. Causes of such fever include septicemic infections with bacteria, known and unknown viruses, rickettsia and protozoa, and organs specific bacterial and viral infections of gastrointestinal tract, respiratory tract and urinary tract. The clinical manifestations of most short duration fevers in the initial phases are not distinctive as was observed in the present study. Empirical treatment of such illnesses with broad spectrum antibiotics by self or community physicians is not unusual often leading to complications, treatment failure and development of antibiotics resistance. The major reason for such empirical treatment is lack of quick and sensitive diagnostic procedures of the above mentioned infections. Diagnostic procedures in the context of enteric fever have been largely unsatisfactory due to low specificity of serological methods in endemic areas and low probability of isolation of $S$. typhi after antibiotic therapy. Newer techniques such as ELISA or DNA probes have not shown much clinical utility.

In the present study thirty one out of sixty suspected enteric fever cases remained undiagnosed from microbiology point of view and seven patients had a diagnosis other than typhoid or paratyphoid. Sixty percent of them had received some antimicrobial agent prior which probably affected the investigations in a large way. Of the 17 cases who were labelled as typhoid, nine had received antibiotics. As a result, culture positivity was extremely low. Widal test in the early phase of the illness could pick up eight cases. However, interpretation of the test remains difficult and the disease can be there even when the test is negative. Pre-investigation antibiotic treatment has probably a role as well in affecting the Widal test results. It was also observed that only two of the Widal negative patients had diagnostic titre in repeat testing a week later while receiving treatment where as in the large majority there was no such conversion. This reflects great individual variations in mounting an immunological response to the infection. PCR was positive in seven patient, of whom blood culture was positive in only one case. False negative PCR in two culture positive cases is difficult to explain and in earlier report 17 we did not encounter this problem. The false negativity in these two cases is possibly due to denaturation of the sample due to problems of storage. Alternatively presence of mutant strains in blood sample can also lead to false negative result. In our earlier study we had suggested a specificity of $93.7 \%$ and sensitivity of $100 \%$ for PCR detection of S. typhi in typhoid ${ }^{17}$. However, when applied in clinical situation, these figures have not been substantiated. Larger studies are required in testing the value of the test especially in presence of prior antibiotics therapy. In the present study five of the seven PCR positive cases had prior antibiotic therapy and all of these were culture and Widal negative in the fistt testing. Thus PCR detection of S. typhi is a useful tool in the diagnosis of enteric fever in situations of prior antibiotic therapy. As PCR assay also requires a critical quantity of DNA in the blood sample, $\mathrm{PCR}$ positivity is also likely to be affected by the duration of antibiotic therapy which results in rapid decline in the load of susceptible infectious agent.

\section{CONCLUSION}

Definitive diagnosis of typhoid is difficult to achieve especially in antibiotic treated patients. PCR detection of $S$. typhi appears to be a useful tool in the di- 
agnosis of typhoid fever in patients with prior antibiotic therapy.

\section{REFERENCES}

1. Edelman R, Levine MM. Summary of an international workshop on typhoid fever. Rev Infect Dis 1986; 8: 329-49.

2. Frankel G, Newton SMC, Schoolnik GK, Stocker BAI. Unique sequences in region of VI of the fragellin gene of $\mathrm{Sal}$ monella typhi. Mol Microbiol 1989; 3: 1379-83.

3. Gilman RH, Terminel M, Levine MM, Hernandez-Mendoz P, Hornick RB. Relative efficacy of blood, urine, rectal swab, bone marrow and rose spot cultures for recovery of Salmonella typhi in typhoid fever. Lancet 1975; 1: 1211-3.

4. Guerra-caceras JG, Gotuzzo-Herencia E, Crosby-Dagnino E, Miro-quesada J, Carillo-Parodi C. Diagnostic value of bone marrow culture in typhoid fever. Trans R Soc Trop Med Hyg 1979; 73: 680-3.

5. Hoffman SL, Edman DC, Punjabi NH, Lesmana M, Choi A, Sundah $\mathrm{S}$, et al. Bone marrow aspirate culture superior to streptokinase clot culture and $8 \mathrm{ml} \mathrm{1:10} \mathrm{blood} \mathrm{broth} \mathrm{culture}$ for diagnosis of typhoid fever. Am J Trop Med Hyg 1986; 35 : 836-9.

6. el Shafie $S$. The Widal test in normal healthy population in Sudan. East Afr Med J 1991; 68: 266-9.

7. Levine MM, Cardos O, Crilman RH, Woodward WE, Solis Plaza R, Waldman W. Diagnostic value of the Widal test in areas endemic for typhoid fever. Am J Trop Med Hyg 1978; 24: 795-800.

8. Gupta AK, Rao KM. Simultaneous detection of S. typhi antigen in serum by as counter immuno-electrophoresis for an early and rapid diagnosis of typhoid fever. J Immunol Method 1979; 40: 373-6.

9. Lim PH, Fok YP. Detection of group D Salmonellae in blood culture broth of solube antigen by tube agglutination using an 0-9 monocloncal antibody latex conjugate. J Clin Microbiol 1987, 25: 1165-8.

10. Rockhill RC, Rumans LW, Lesmana M, Denis DT. Detection of $S$. typhi $\mathrm{O}, \mathrm{Vi}$ and $\mathrm{D}$ antigens by slide coagglutination in urine from patients with typhoid fever. J Clin Microbiol 1980; 11: 213-6.

11. Barret TJ, Snyder JD, Blake PA, Feeley JC. ELISA for detection of $S$. typhi Vi antigen in urine from typhoid patients. $\mathrm{J}$ Clin Microbiol 1982; 15: 235-7.

12. Taylor DN, Harris JR, Barret TJ, Hargrett NT, Prentzel I, Valdivieso $\mathrm{C}$, et al. Detection of urinary $\mathrm{Vi}$ antigen as a diagnostic test for typhoid fever patients. J Clin Microbiol 1983; 18: 872-6.

13. Rubin FA, McWhirter PD, Punjabi NH, Lane ED, Sudarmono P, Pulungsi.sh SP, et al. Use of DNA probe to detect Salmonella typhi in the blood of patients with typhoid fever. J Clin Microbiol 1989; 27: 1112-4.

14. Faundez G, Aroni C. Chromosomal DNA, iron transport system, outer membrane proteins and enterotoxin (heat labile) production in Salmonella typhi strains. J Clin Microbiol 1990; $28:$ 894-7.

15. Song JH, Cho H, Park MY, Na DS, Moon HB, Pai CH, et al. Detection of Salmonella typhi in the blood of patients with typhoid fever by polymerase chain reaction. J Clin Microbiol $1993 ; 31: 1439-43$

16. Hashimoto Y, Itho Y, Fujinaga Y, Khan AQ, Sultana F, Miyake $\mathrm{M}$ et al. Development of nested PCR based on ViaB sequence to detect Salmonella typhi. J Clin Microbiol 1995; 33: 775-7.

17. Chaudry R, Laxmi BV, Nisar N, Ray K, Kumar D. Standardisation of polymerase chain reaction for detection of Salmonella typh i in typhoid fever. J Clin Pathology 1997; 50: 437-9.

18. Brown GW, Shirai A, Jegathesan M, Burke DS, Twartz JC, Sanders JP et al. Febrile illness in Malaysia -an analysis of 1629 hospitalised patients. Am J Trop Med Hyg 1984; 33: 311-5

19. Anderson KE, Joseph SW, Nasution R, Sunoto, Butler T, Van-Peenen-PF et al. Febrile illness resulting in hospital admission: a bacteriological study in Jakarta, Indonesia. Am J Trop Med Hyg 1976; 25: 116-21. 